ÉGYPTE

monde arabe

\section{Égypte/Monde arabe}

1 | 2005

Le shaykh et le procureur

\title{
Mobilizing islam and custom against statutory reform: bayt al-tấa in Yemen
}

\section{Anna Würth}

\section{(2) OpenEdition}

\section{Journals}

Édition électronique

URL : https://journals.openedition.org/ema/1908

DOI : 10.4000/ema.1908

ISSN : 2090-7273

\section{Éditeur}

CEDEJ - Centre d'études et de documentation économiques juridiques et sociales

\section{Édition imprimée}

Date de publication : 30 juin 2005

Pagination : 277-298

ISSN : 1110-5097

\section{Référence électronique}

Anna Würth, «Mobilizing islam and custom against statutory reform: bayt al-tấa in Yemen », Égypte/ Monde arabe [En ligne], 1 | 2005, mis en ligne le 08 juillet 2008, consulté le 07 juillet 2022. URL : http:// journals.openedition.org/ema/1908; DOI : https://doi.org/10.4000/ema.1908

Ce document a été généré automatiquement le 7 juillet 2022.

Tous droits réservés 


\title{
Mobilizing islam and custom against statutory reform: bayt al-tấa in Yemen
}

\author{
Anna Würth
}

\section{NOTE DE L'AUTEUR}

I would like to thank Yemeni activists for their willingness and time to discuss their thoughts with me; Baudouin Dupret and Kilian Bälz for their concise comments on earlier drafts; François Burgat, CEFAS staff and guests for their outstanding hospitality and help in Sancâ'. I am also indebted to an unnamed friend for clarifications on the dynamics of $t \hat{a}^{c} a$ that are not found in legislation or court judgements.

1 In August 2000, the Parliamentary Committee for Justice and Awqâf issued its report on the amendment of Law 28/1992 on Civil Procedure and Execution of Judgements. The amendments suggested, inter alia, giving the executing judge (qâdî al-tanfîdh) complete discretion to force a disobedient wife (zawja nâshiza) back to her husband's home, thus adapting the Egyptian model of bayt al-tâca. ${ }^{1}$ Most unlike other recent reforms of Yemeni family law (Würth, 2003), this draft caused an uproar among non-governmental organizations (NGOs), which spread to journalists, lawyers, some judges and religious figures, and resulted in the articles in question being dropped from the law. This present discussion will argue that the NGO campaign was successful because it was based on an amalgam of customary and Islamic norms in defense of the legislative status quo. Implicitly, activists of all political shades also argued that the control of paternal relatives over women correlates to male protection for women in cases of marital conflict and in the absence of state interference into "family affairs."

2 For this article I have relied on newspaper material and interviews with judges, lawyers and NGO activists. To illustrate current jurisprudence, I have used an arbitrary selection of about thirty personal status law rulings issued by the Court of Appeal for 
Sancâ' and al-Jawf, ${ }^{2}$ thus consisting of cases from a rural environment. ${ }^{3} T$ These rulings contain appeals to cases heard at Courts of First Instance and to cases decided by arbitrators under customary law.

\section{"Angry" wives}

3 "Running-away angry" (hanq) from one's husband occurs frequently in Yemen, particularly among the recently married and those with small children (Mundy, 1995:131, 141 ; Würth, 2000:162-166). Depending on the circumstances, "running-away" might last for an afternoon, a week, but also months, and some wives spend years living at their relatives. As this indicates, "running-away angry" is only an option for women who have relatives to turn to, and is most feasible for those who have family nearby. ${ }^{4}$ Again, depending on the individual family's material and psychological circumstances, the pressure to return to the husband varies. If a woman has married up the social scale, some families fear social isolation, and force her to return. Some force an unhappy daughter/sister back, simply because they cannot or do not want to house and feed more people. One woman recounted to the Court of Appeal: The defendants [her husband and her father] agreed to submit to arbitration ... and agreed secretly among themselves. My father forced me to return to the defendant [the husband] but life did not improve (wa lâ fầida). Then I ran away and asked the defendant to divorce me ... and he agreed in the presence of the local notables ... but my father forced me to return. And I never experienced anything with the defendant [the husband] but insult, tiring work, exhaustion and bad treatment ... and [my father] helped him to force me back one time after the next for five years. ${ }^{5}$

4 Other families are enraged that the husband appears to have mistreated their female relative, and refuse to let her go back. While in most cases the wife will have left her husband's home because of problems and irritations in the marriage, sometimes marital trouble is caused by the in-law relationship, particularly if the husband and his in-laws have had financial dealings outside the marriage. As the husband of the abovementioned wife explained: "Her father is the reason for her running away and being disobedient (sabab fî kharabihâ wa khurûjihâ can tâcatî) and I am having a dispute with him."(ibid.) Those conflicts tend to be the most exacerbated: whatever the wife's personal relations with her husband, she might find herself a pawn in an ever broadening circle of conflict, and possibly violence.

5 Overall, how the paternal family reacts towards marital trouble experienced by one of its female members is as diverse as the reasons for the marital disputes themselves. ${ }^{6}$

\section{On how to return a wife: negotiation, arbitration, and court proceedings}

6 Whatever the reasons for the wife going back to her relatives' house, the husband should approach his in-laws or send mediators to start negotiations about her return. Most families will insist on being reimbursed for the costs incurred during the woman's residence with her paternal family; some insist in addition on compensation for the wife (a new set of clothes or gold) and for the in-laws, such as slaughtering a sheep. Families may also demand a written statement (iltizâm, tacahhud) from the husband 
undertaking to treat his wife decently, particularly if the husband had been violent, overly strict with his wife, or did not provide for her properly.

7 Negotiations about a wife's return can be protracted, thus prolonging her stay at her father's house and being a strain on everybody. If mediation does not resolve the conflict, parties may turn to arbitrators, ${ }^{7}$ often incurring considerable costs and not always being successful. All cases that come to court have therefore had a history of informal negotiations, mediation attempts and - depending on regional origins arbitration; accordingly, parties at court will be frustrated and exasperated, but with high hopes that the court action will effect a decisive change in their favor.

8 Implicitly, Yemeni Personal Status Law takes customary norms and procedures into account and does not provide for explicit sanctions should a "disobedient wife," as the legal parlance puts it, fail to return to her husband. Under the law, a wife's foremost duty is obedience $(t \hat{a} a)$, entailing that, with a few exceptions, she cannot leave the marital home without her husband's permission. ${ }^{9}$ If she does so for extended periods the husband's only recourse is to suspend maintenance by filing a court action for the restitution of marital rights (tâa $a$, irjâcal-zawja). But even if the court rules in his favor, a husband has no way of having his wife physically brought back to his house. ${ }^{10}$ Likewise, Yemeni wives have very limited possibilities of actually obtaining court ordered maintenance. Even if a wife's claim for maintenance is validated by a court ruling, the decision remains largely symbolic, ${ }^{11}$ since it is not backed up by the enforcement apparatus of the state. Additionally, many, if not most, husbands who are dragged into courts are too poor to provide adequately for their wives.

9 Court action is often taken by the runaway wife herself, or rather, by her family, suing for marital maintenance and the provision of adequate housing. In response, the husband will often file a counter-claim for marital obedience, or simply respond to his wife's claim by denying her entitlement to maintenance. ${ }^{12}$ Regardless of who initiated the proceedings, judges tend to adjudicate the whole issue in one ruling, that is, the right to maintenance/housing and the return to the husband.

10 Husbands will often cite the wife's paternal relative as at least co-defendant, if not sole defendant, and have the claim registered as "wife kidnapping" (nahb al-zawja) by the court scribe. This aptly captures the common notion that marital conflicts ultimately constitute an infringement of men's rights and should be dealt with as such (Dresch, 1989:56). If the wife is not the defendant, the ultimate decision will involve her only as an object that her relative has to return to her husband; but many judges will insist that the wife is actually brought to court and is heard before they issue a ruling. In order to force the paternal relatives to comply with a decision to return the wife, an insistent husband might have them temporarily detained. The legal status of this detention is rather doubtful, but is common practice regardless. ${ }^{13}$ If, on the contrary, the wife is the defendant, the husband has no possibility of directly enforcing the ruling if the wife and her family refuse to submit to the court's decision, and his only recourse will be to suspend her maintenance.

11 The amendments to the Civil Code of Procedure and Execution of Judgements, detailed below, suggested a change to the lack of direct enforceability of rulings on marital obligations. If, after a court ruling, negotiations between spouses or, rather, between families, about implementing the ruling, came to an impasse, the state would intervene. The detention of paternal relatives would be recognized as a legal means of enforcement, as would a jail term for husbands not paying court-ordered maintenance. 
A wife could either be sent to jail or returned to her husband with the assistance of the police.

\section{Jurisprudence: differences and commonalities in Court and Arbitration rulings}

\section{Keeping the family together}

Claims for marital rights, that is, for maintenance/housing and obedience, involve fairly irreconcilable claims and aims. Husbands demand their wives back without paying for past maintenance and/or compensation, while wives and their families condition a return upon fulfillment of these financial requests and the provision of adequate housing. ${ }^{14} \mathrm{From}$ earlier work on court rulings in one primary court in San'â', it appeared that First Instance Court judges very often tend to sustain both claims. The wife is awarded maintenance for the time she spent at her father's house, and her father is obliged to return her to her husband's house. ${ }^{15}$

Arbitrators' rulings are strikingly similar in this respect, as the following few examples may illustrate. One husband is required to pay YR60.000 (US $\$ 400)^{16}$ to his father-in-law for the time his wife and children spent at her family's house, and to provide appropriate housing for her, far away from her co-wife. Then the wife has to return. ${ }^{17}$ In another case, arbitrators ruled that:

Amîra ... returns to the house of her husband ... as soon as [the husband] pays her and her children maintenance for ten months, YR40.000 (US\$266), furnishes a house in the spouses' place of residence ... and promises to provide for her and live with her respectfully. In addition, [the husband] has to offer two sheep to his uncle/ father-in-law, with YR5.000 and another YR5.000 (US\$33) for a new set of clothing (kiswa) for the wife. ${ }^{18}$

In another case, arbitrators failed to find proof of the competing claims, and handed down the following decision:

The first party, the husband ... has to bring a guarantor (damin multazim), prepare proper housing and live respectfully with his wife, and provide for her adequately. The second party ... [the wife's father], has to bring a guarantor (damîn multazim calayh) and return his daughter to her husband's house, and oblige her to be obedient towards her husband. ${ }^{19}$

As these examples show, arbitrators appointed by the parties and state-appointed judges do not enunciate decidedly different norms. They attempt to keep the nuclear family together by validating the claims of both spouses, and resort to requesting guarantors to oblige the husband and the wife's father to maintain future good behavior. Unlike judges, arbitrators address in addition the in-law relationship, and may request the husband to slaughter sheep for his father-in-law, "to pacify" (tatyîb khâtir ammih) him, as it is expressed in numerous rulings. Under customary norms, compensation is paid to bring moral balance back into a relationship that has publicly fallen out of balance; making amends in this way expresses an apology and an imposition at the same time (Dresch, 1989:50, 56, 58). Since relations between in-laws do not come within the ambit of statutory law to begin with, judges will usually not oblige the husband to compensate his in-laws. But if there is a valid arbitration ruling or a previous obligation to provide compensation in kind or money to the in-laws, many judges will honor this and incorporate it into their own ruling. 


\section{in-laws constitutes admission of wrongdoing, an argument refuted by an angry} husband in the following terms:

The [First Instance] judge made another mistake in arguing that [the husband] slaughtered two sheep for his father-in-law ... so he would return his wife ... [The judge considered that] this is evidence that the [husband] committed a mistake. But this is a faulty argument ... since it cannot be considered legally relevant proof (dalil min adilla al-ithbât). It is ... the 'urf in Yemen ... that one slaughters a sheep for one's father-in-law to return [a wife], whether one made a mistake or not. ${ }^{20}$

Customary norms in respect to the in-law relationship thus enter judicial proceedings in several ways and, in these cases, are often validated by judges.

\section{Legal proceedings}

Legal proceedings before judges and arbitrators are essentially the same. Judges and arbitrators alike are bound to adjudicate only what was requested by the parties. In both fora, the plaintiff's claim and the response of the defendant need to be presented, and essentially the same rules of evidence apply, i.e. the plaintiff has to prove his/her claim, preferably by witnesses, which, particularly in family law, is often difficult. Arbitrators often encounter parties who have no proof for their assertions, but rarely would a judge express his exasperation in the way that these arbitrators did:

We requested from each party that they present their claim (dawwâ) and a reply (ijâba) to the claim of the other side. Then evidence (barâhîn) and witnesses were requested. Neither of the parties could prove [his claim] with witnesses, and each side denied what the other side claimed. This went back and forth (wa zâda al-akdh wa-l-radd) and all [their] claims were just assertions [of the kind] 'he said and I said,' which did not deserve that we waste our time with it. ${ }^{21}$

There are, however, essential legal differences between court and arbitration proceedings that relate to formalization, jurisdiction, and parties' consent. Unlike arbitration rulings, court judgements are very formalized, since they go through a lengthy process of claim reformulation by legal professionals. Thus a claim of "wifekidnapping" registered by the plaintiff with the court scribe will eventually be processed into a claim for "return/obedience of the wife." Arbitration rulings are much less formalized; although they also narrow down competing social claims into adjudicable facts, they lack the technical language and legal reference employed in court rulings.

20 As to jurisdiction, arbitrators are permitted to rule on all family law matters except for wife-initiated divorce (faskh), a right reserved to judges alone. ${ }^{22}$ In one case, a husband turned to the Appeal Court to have an arbitration decision voided, whereas the wife's father requested that the ruling be implemented. The Appeal Court voided it, since the arbitrators had not specified the parties' claims and had ruled on the "validity of talâq by the wife" [sic!], in violation of the law on arbitration. In this, as in a comparable case, the Appeal Court referred the parties to the competent primary court to initiate proceedings. $^{23}$

21 Unlike court proceedings, arbitration requires the consent of the parties, often in written form. The parties need to authorize and empower (tafwid) the arbitrators to resolve the conflict on their behalf. It is very rare that a wife authorizes arbitrators herself, or gives formal consent (in form of a power of attorney) to a male family

Égypte/Monde arabe, 1 | 2005 
member to authorize arbitration on her behalf. Choosing and authorizing arbitrators is an all-male reserve. This is a common defense against enforcement of an arbitration verdict. One woman appealed to the court to void the arbitration ruling that had returned her to her husband's home. The Court of Appeal found that her father had failed to obtain her power of attorney before authorizing arbitration proceedings, and voided the ruling. ${ }^{24}$ In another appeal on the same grounds, the husband admitted that his wife did not authorize her father to engage in arbitration:

The person who authorized (fawwada) [the arbitrators] ... was [the person] who has authority over her (al-qâ'im bi-amrihâ) and [also the one] who is insubordinate and inciting her (al-mutalấcib wal-mutamarrad lahâ), that is her father and her guardian (sâhib ${ }^{c}$ ismatihâ). Her father is not a stranger to her (laysa bi-ajnabî ${ }^{c}$ anhâ) who would require a power of attorney for arbitration..${ }^{25}$

Legally, this argument disputes that the arbitrators had acted outside the powers conferred on them. Socially, the husband expressed the customary assumption that the guardianship by paternal relatives over a woman never ends, and need not be formalized by a power of attorney, which is seen as a necessity only for "strangers", that is, lawyers. In a third case, the Appeal Court voided an arbitration ruling because neither husband nor wife had authorized the arbitrators - their fathers had done so. ${ }^{26} \mathrm{In}$ other cases, arbitrators had failed to establish a wife's consent to a divorce that involved giving up her financial rights vis-à-vis her husband (khul), thus making the respective ruling amenable to being quashed on appeal. ${ }^{27}$

To sum up, arbitration and court proceedings differ decisively in legal terms. Whereas the former represents a judgement by a private person based on the parties' consent, rendered pursuant to a legally recognized procedure and considered enforceable upon registration with courts, in the latter, the dispute is solved by a state institution, that is, a court. Despite this difference, there are essential commonalities between arbitration and court judgements: in substance, arbitrators and judges attempt to hold the nuclear family together, and arbitrators also do so by attempting to take the larger social context of the conflict into account, that is, the in-law relationship in particular. Another commonality relates to the question of a wife's representation both in arbitration and court proceedings. Very often wives are not formally represented, and therefore arbitration rulings, like many First Instance Court rulings, may be - and often are - quashed on appeal due to violations of formal requirements in statutory law.

\section{Financial implications: costs of returning a wife and of divorce}

24 A substantive difference between decisions of judges and arbitrators lies in the financial implications of their rulings. While courts usually do not award monthly maintenance of more than YR1.000-2.000 (US\$6-\$12), arbitrators award at least double the amount in cash and clothes/gold, and also award compensation - cash and sheep to the in-laws. The amounts awarded not only reimburse the wife's paternal family for the costs incurred, but are of symbolic value to pacify the in-laws. Court-awarded maintenance works the other way round. It does not cover the costs incurred while the wife was staying with her family, but is almost entirely symbolic and serves to validate the wife's claim that she left the husband's home for a "proper" sharî reason, and not because of "disobedience". than arbitration, since it clearly reduces his financial burden for the return of his wife. 
One example might illustrate this. In April 1998, a young wife, Amîra, ran off to her father's house, claiming that she could not stand her husband. The local judge in the district's primary court persuaded them to conclude a settlement (sulh), whereupon it was agreed that the husband should pay YR20.000 (US\$133) in past maintenance and that the wife would return. When this did not happen, the parties resorted to arbitration. The arbitrators reached a similar conclusion, but requested the husband to pay her maintenance of YR40.000 (US\$270), in addition to another YR10.000 (US\$67) for his father-in-law and clothes for the wife. Again, he did not pay and the wife did not return. The Appeal Court - to which the husband then turned to have the sulh negotiated by the first court implemented - ruled in his favor. Amîra had to return, and was awarded the YR20.000 in past maintenance that they had originally settled for at the First Instance Court, and her divorce petition was denied by the Appeal Court. ${ }^{28}$ This train of events illustrates how the results of the rulings by the two courts were financially much more advantageous to the husband than the arbitrated solution.

Another substantial difference between arbitration and court rulings relates to the costs of divorce initiated by the wife. Arbitrators and judges alike are aware that marital disputes on maintenance/obedience very often end up in divorce. Arbitrators are not permitted to issue any divorce rulings against the wishes of the husband - this being the courts' prerogative under the law (see above). The most that arbitrators can do is either to oversee the repudiation of the wife or lay down conditions for a future khul. In general, customary norms on divorce at the wife's initiative almost always prescribe khul settlements, often for substantial amounts of money, as the following examples from arbitration rulings show.

After having ruled that the wife was to return to her husband upon his fulfillment of her marital rights, two arbitrators added:

... if the wife refuses to return to her husband's house, and requests a divorce (talâq) then ... [her father] has to pay YR250.000 (US\$1.667) to the first party [the husband] ... who is then obliged to divorce [his wife] and return all her clothes from his house. The talâq shall occur after he saw his wife, and requests that she forgives him... Their girl is to be returned to her father. But if the mother requests custody (haqq al-wilâya) over the child, she will stay with the mother and ... [the mother's father] is obliged to pay for her expenses and clothing until she turns major. ${ }^{29}$

In another case, arbitrators first ruled on the return of the wife and payment of past maintenance, then continued: "Amîra ... has no right to maintenance and custody if she does not step back from her refusal (karâhiya) to return to life in the marital household under the conditions we specified above, but then she must compensate her husband (tawîld) ... by YR200.000 (US\$1.333) to obtain a divorce. ${ }^{30} \mathrm{~A}$ further case came to a Court of First Instance when a mother sued her ex-husband for child abduction after the divorce, while the husband claimed that custody of the child was part of a khul settlement concluded by tribal leaders. The tribal leaders appeared in court and testified that they had adjudicated the case in 1997, obliging the wife's family to pay the husband YR240.000 (US\$1.600) for the khul divorce. The First Instance Court found that custody was not part of the khul settlement, whereas the Court of Appeal quashed the ruling, validating the khul for the amount specified and for giving up custody of the common child. ${ }^{31}$

With the rise in the cost of marriage since the mid-1970s, costs for a no-fault, consensual khul divorce have likewise exploded, including not only the sum paid as mahr, but also part of the wedding expenses and the money paid to the wife's father 
(shart). For the rural and urban poor, the sums usually requested for khul are clearly beyond their means; even if there is a margin for negotiation once a family is set on khuldivorce, the amounts are still high. Therefore many women ultimately turn to the court, where they will have to prove their case, i.e. that the husband has violated his marital obligations beyond reconciliation, but the overall expenses for a court divorce (faskh) are significantly less. For women who can prove their right to a divorce, courts are an important recourse and more advantageous than arbitration under customary norms. ${ }^{32} \mathrm{On}$ the other hand, for women with social and monetary resources, the khul mode of divorce, negotiated on their behalf by male relatives in an arbitration setting, is the single most widespread and convenient way out of an unhappy marriage particularly if the husband did not violate his legal obligations towards her.

To sum up, depending on the case in hand, arbitration rulings offer different advantages to men and women. If the issue is maintenance for a "runaway" wife, arbitration rulings are more advantageous to the woman and her family, and often constitute a considerable financial burden on the husband, because the return of the wife will also require payment of customary compensation to his in-laws. If the issue is divorce, especially if husbands have violated their marital obligation, courts offer women a financially more attractive option, but also the risk of having a divorce petition denied. Formal and informal means of justice may thus have different effects on litigants, depending on gender, social class, and the legal issue at hand.

\section{Enforcement}

31 Theoretically, courts and the arbitrators - who are often tribal leaders or local strongmen - as well as government officials, have access to the same means of enforcement, i.e. to the government, police or soldiers. In addition, many tribal leaders and local strongmen command soldiers and prisons of their own and use these powers to intervene in family conflicts. Thus one husband complained to the Appeal court that "my cousins forced me (ghasabûnî) to repudiate my wife," while the wife's relatives declared that the husband had agreed to an arbitrated khul divorce for YR80.000 (US\$533), of which YR10.000 (US\$67) was paid and YR70.000 (US\$467) was recorded as a debt to be paid in one year's time. Whereas the First Instance Court in al-Hayma alKhârijiya had ruled on the validity of the khul divorce, the Appeal Court was of a different opinion. They heard the witnesses to the divorce, who testified that the husband was threatened by a local shaykh and taken to a separate room "to make him understand that either he divorces, [or] will be beaten up or jailed." The husband also presented the order of the local shaykh to have him jailed (mahbûsiyya) should he continue to refuse to grant the repudiation. ${ }^{33}$

Arbitrators usually fine parties more often than judges, who use this instrument only in exceptional cases. In one ruling, the arbitrators spelled out that "non-implementation or procrastination (mumâtila) will be punished with a fine or jail (habîs)," and submitted the case to the local security authorities. ${ }^{34}$ In another case, a First Instance judge had concluded a settlement before the parties turned to arbitration. The original settlement required the wife's father to return the wife to her husband after he had paid YR20.000 (US\$133) for her past maintenance. As the husband claimed to have paid his share, and the wife did not return, the wife's father was jailed twice. It is not clear from the ruling on whose initiative this occurred ${ }^{35}$ In another case, the wife's father was likewise jailed 
several times for his refusal to return his daughter to her husband after an arbitration ruling. The husband had already slaughtered two sheep and then, in exasperation, turned to local security and shaykhs for help. Ultimately, the wife successfully filed for divorce at the First Instance Court, and this was upheld at the Appeal Court. ${ }^{36}$

Arbitrators and judges alike confront the problem of enforcement in marital disputes. Force can only be employed against the wife's paternal relatives, and not against the wife herself. Compliance with a court ruling is thus subject to more negotiations between the families, and rulings serve as a bargaining chip in these processes. Enabling a husband to return his wife by police enforcement, as the amendments had suggested, would thus have decisively strengthened the husband's position vis-à-vis the in-laws and his wife.

\section{Enforcing obedience: law reform}

Like most Yemeni legislation from 1990 to 1994, Law No. 28/1992 on Civil Procedure and Execution of Judgements was issued by presidential decree (Würth, 2000:45, 50 ; Glosemeyer, 1999:82) and acknowledged by parliament only seven years later, in July 1999. According to the preface of the draft law, parliament then requested that the decree-law they had just passed be retroactively revised. The Committee for Justice and Awqâf, headed by Abdallah Sinân al-Jalâl, ${ }^{37}$ set to work, relying on the support of some experts from the Faculty of Law and the Ministry of Justice. ${ }^{38}$

One of the explicit goals in revising the law was to facilitate stricter and more uniform implementation of rulings, the lack of which is one of the main shortcomings in the Yemeni judicial system. To this effect, the power of the executing judge was increased and, at the same time, provisions for suing judges for, inter alia, corruption, misconduct and grave professional mistake, were introduced. ${ }^{39}$

In regard to the enforcement of court decisions handed down in maintenance and marital obedience suits, the draft deviated considerably from the current law and practice outlined above. In general, the draft permitted jailing for civil debts, which was explicitly forbidden under the previous law (Art. 252b). Article 359 (b) of the draft even permitted jailing of a debtor's paternal relatives, should the debt owed consist of maintenance. Article 358 further stipulated that "[a] claim of poverty is not heard during execution of judgement ... but the debtor has to go to jail until what is owed by virtue of the title (sanad tanfidhî) is paid up." In theory, this would give women the possibility of obtaining a jail term for those husbands who fail to pay court-ordered maintenance. In practice, the provision is of uneven application, depending on the husband's financial ability. In a parallel fashion, the draft extended the possibilities for a husband to enforce a tâa ruling, as draft article 371 provided that: "If the object of execution is to move (intiqâl) a wife to the marital house, the court clerk gives her official notice (ishtâr rasmî). If she fails to comply, the judge can execute the order by forcing her in a way he finds appropriate as long as she does not have a sharî reason."

The committee explained this (and other) suggestions in the relevant subchapter by claiming lacunae in the existing provisions. These lacunae lead "the courts [to] execute [judgements] by ijtihâd resulting in differences in legal solutions..." The new provision of Article 371 would facilitate procedures and stop the arbitrariness (tahakkum) of judges. As the committee further explained, only if the official notice failed to convince the wife to submit to the court ruling could the judge use any means he sees fit - fine 
her, or use force (istikhdâm quwwa), that is, either jail her or use police force, or suspend her maintenance. ${ }^{40}$

The draft law failed to detail the technicalities of the official notice. Thus no time period was set within which the wife was supposed to comply with the notice, leaving it up to the judge's discretion. It also failed to provide for precise regulations on how to submit the notice to the wife; did the rules of summons apply? That is, did it need to be signed and witnessed upon delivery? And if signed by proxy, would it still obligate the wife, considering that most young married Yemeni women would not want to be caught dead conversing with a court usher?

Regardless of the draft's technical shortcomings, its intention is clear. It aims to provide both spouses with more state-backed measures and protection to enable the enforcement of their marital rights as pronounced by court rulings. However, in actual practice the Egyptian-style innovation would have probably worked more to the advantage of men, since jail terms for recalcitrant husbands would not have had much effect on the majority of litigants at Yemeni courts, who do not pay maintenance because of their poverty.

\section{Employing Islam and custom against law reform: the NGOand press campaign}

The news on the impeding change in the law was leaked to the public by Muhammad Nâjî́Alaw, a member of parliament, lawyer and human rights activist. ${ }^{41}$ According to one report, ${ }^{\mathrm{c}}$ Alaw was in a meeting between some parliamentarians and representatives of the United Nations Population Fund to discuss the legal position of women in Yemen, when he broke the news that a "bomb was waiting for women." ${ }^{22}$ In November 2001, he issued a press statement in the name of one of his NGOs, and declared the articles to be against the shari ${ }^{c} a{ }^{43}$ This argument was taken up by all the other organizations. The Yemeni Women's Union in Tacizz and Aden held meetings in which they additionally condemned the draft as "returning women to Ottoman times ('ahd al-harim). ${ }^{{ }^{44}} \mathrm{The}$ Human Rights Information and Training Center (HRITC), based in Tacizz, togetherwith the Arabic Sisters' Forum (muntadâ al-shaqâ'iq al-carabî), based in San'â' under the energetic Amal Bâshâ, released similar statements. They added that the articles would contradict Yemen's international obligations under the Convention against the Elimination of all Forms of Discrimination against Women (CEDAW) ${ }^{45}$ The Civic Democratic Initiatives Support Foundation (mu'assasa $\mathrm{da}^{c} m$ al-tawajjuh al-dîmûqrâtî), with its Women's Affairs Support Center (markaz li-musânada qadâyâ al-mar'a), were likewise active in lobbying against the draft's provisions, using a combination of all of these arguments. ${ }^{46}$

41 Among the parties, only the Yemeni Socialist Party (YSP) issued a statement condemning the draft as retrograde, ${ }^{47}$ but individual officials of the ruling General People's Congress (GPC) and the Islâh criticised the law. cAbd al-Fatâh Butûl (Islâh) called the draft a "dangerous ijtihâd", ${ }^{48}$ and Alî Hamûd cAzîz (GPC) stressed that the Quran is usually interpreted by men, who might have a negative stance towards women. This, in turn, would result in provisions "treating women like cattle." ${ }^{49}$ Long-time GPC Minister for Legal and Parliamentary Affairs, Abdallah Ghânim, also criticised the draft and claimed that the government had no prior knowledge of it. He found that it contradicted "the principles of women's rights and the principles of the rights of the 
family, because marital life can not be imposed by force (ishra bil-quwwa)." ${ }^{50}$ Ibtihâj alKhayba (GPC) stressed that the provision was against the constitution and international conventions, whereas, interestingly, former YSP member of parliament, Khawla Ahmad Sharaf, pointed out that it was against the Quran. ${ }^{51}$

Many perceived that these articles could have only been suggested by extremely reactionary members of the religious community. One cartoon published in al-Shûrâ, the weekly journal of the Union of Popular Forces, showed a woman saying "zahara alhaqq (the truth appeared)" pointing to a mosque bearing the inscription bayt al-tâa $a$. Similarly, the late Jâr Allah cUmar, vice-secretary of the YSP, described the draft article as "a simple provision written by a country-bumpkin jurist while chewing qât (nass basit yaktubuhu faqîh fil-maqyâl)." ${ }^{2}$ Only Muhammad Nâjî̀ cAlaw pointed out that those who devised the new provisions appear to have been the experts the committee had relied on. They were university professors who had received their legal education in Egypt, ${ }^{53}$ and who had previously been perceived in Yemen as a guarantee of progressiveness in legal and social thought. ${ }^{54}$

All critics, whatever their political background and convictions, agreed that returning a wife by force to her husband was against the shari $a$, without, however, making further specifications. Many added that it was therefore also against the constitution, which in Article 3 required that the sharîa was to be the sole source of all legislation. ${ }^{55} \mathrm{Izz}$ al-Dîn al-Asbahî, head of the Tacizz based HRITC, contemplated filing for a constitutional review of the articles should parliament pass the law. ${ }^{56}$ Some also pointed that all other "Islamic states" had annulled comparable provisions, so why should Yemen, which had never known the institution of bayt al-tâca, introduce it? ${ }^{57}$ They claimed that this type of retrograde legislation would ruin Yemen's reputation as a "leading nation in the codification of the sharîa", and also cast doubt on the compatibility of Islam with international human rights norms. ${ }^{58}$

In another argument, relying more on customary norms, activists were apprehensive that such provisions would lead to criminal offenses between family members (probably having in mind murder by the husband), or to strife between tribes, since, as one activist mockingly explained: "Hâshid would block all roads to Sancâ' should the police attempt to return one of their women to a Bakîl husband." ${ }^{59}$ In the same vein, YSP member Dhikrâ 'Abbâs reasoned: "What husband will accept, even in a moment of extreme fury (ghadhab) ... such a humiliation (mahâna) for his wife? And will this man also accept this humiliation for his sister, daughter or mother?" ${ }^{60}$ Another questioned: "Are men in need of the force of law and relying on it to force a wife, who is weak (makhlûq daĉf), to obey him ... Manliness (al-rujûla) is not in need of a law to protect or defend itself." 61

Both these women appealed to patriarchal norms and conjured up an image of the ultimate loss of manliness: a man, unable to make his wife love and stay with him, has recourse to the impersonal nature of the police to force her back, instead of swiftly acknowledging his failure in marriage and divorcing his wife when she so requests, thus "respecting himself", as the customary parlance describes this behavior. The implicit aspect of this argument relates to the sharî and to the tribal logic of patriarchy: men's control over women becomes unacceptable if not coupled with male protection in times of conflict. If a woman cannot rely on her family to solve marital disputes, but can be forced by police to return to her husband despite her wish, then patriarchal control over women, particularly choosing a spouse for her, is intolerable. 
did not spell this out in the respective article. In addition, it is doubtful whether a new legal definition of guardianship over women was indeed well-placed in the law on civil execution. The committee also defended the draft by stressing that during the proceedings of the initial claim at the competent court, the wife will either have sued for divorce (talâq lil-darar, faskh lil-aib or khul lil-karâhiya as the committee specified), ${ }^{66}$ or will have agreed to return, if her husband provided her with appropriate housing and maintenance. This way, the committee argued, no wife who was unwilling to live with her husband would be forced back to him. Here, the committee chose to ignore that under Yemeni law, suing for a divorce and obtaining a divorce might be two quite different things.

explanations submitted by the committee failed to convince the NGO community, which had decided in the meantime to be on the safe side and submit the issue to the president instead of waiting for a decision from parliament. ${ }^{67}$ However, there was some difference about what to request from the president. Sucâd al-cAbsî, head of the Tacizz branch of the Yemeni Women's Union, publicly requested that he refer the law to the ulamâ' for an opinion (fatwâ). ${ }^{68} \mathrm{Amal}$ Bâshâ, of the Sancâ'-based muntadâ al-shaqâ'iq alcarabî, could hardly conceal her exasperation. "Leave us alone with the culamâ'," she claims to have told her colleague. "If we leave the matter to them, that will bring about an even greater catastrophe." "Laywers Muhammad Nâjî cAlaw (Islâh) and Muhammad al-Mikhlâfî (YSP) concurred; requesting an opinion from the fatwâ-council was unconstitutional, since the fatwâ-council had no legislative authority and this might set a double-edged precedent. ${ }^{70}$ 
50 'Alaw's criticism was not shared by another Islâh member, 'Abd al-Fatâh Butûl, ${ }^{71}$ or by law graduate and MP Alî Abdallah Abû Hulayka (GPC), who similarly stressed the president's prerogative "to refer legislation to any authority." In his view, the fatwâcouncil was competent to look into the draft, since "the issue was related to shari $a$ and figh, and not to the constitution." "72In the end, the president did transfer the law to the fatwâ-council as had been suggested but - in a very Yemeni move - the fatwâa-council refrained from issuing an opinion. Alî Abdallah Salih therefore instructed parliament to annul the articles, and the NGO community celebrated a victory.

51 The united stance of NGOs, lawyers and journalists, irrespective of political affiliations and gender, was impressive. Several factors may explain why the campaign was so successful. First, it appears that its success hinged upon framing opposition against the draft in very broad normative terms, and that voicing opposition on grounds of constitutional and international norms alone may have not achieved the same result, but polarized the debate. Second, the debate attracted a large number of urban professional men, who appear to have felt their personal honor to be at stake, should any of their female relatives be forced back into an unhappy marriage by force. Another factor for the campaign's success may have been that it mobilised an appeal to Islamic and other norms to keep the status quo - which is probably always an easier campaign to conduct than one aiming at changing it. If appealing to a very broad, legally unrefined, concept of sharîa was the common denominator between all groups engaged in the debate, it remains to be seen whether that same strategy will be turned against them in any following struggle, particularly about personal status law - but such are the risks of $\mathrm{NGO}$ activism.

\section{Conclusion}

The first part of this chapter demonstrated that jurisprudence by state-appointed judges and party-appointed arbitrators in respect of marital obligations is not markedly different in underlying norms and aims. Likewise, rulings issued by either of them are an important part in the process of negotiations between spouses and families in times of marital conflict. This demonstrates that formal and informal fora of justice cannot be seen in isolation or as being at loggerheads; rather, they form a normative continuum. This is even more so when one considers that litigants often take up proceedings in both fora, simultaneously or consecutively.

Drawing on these findings, the second part of this article discussed the efforts at statutory reform, aimed at providing both spouses with state-backed enforcement mechanisms in respect of marital obligations. These reforms would have partly relieved litigants of the need to negotiate the terms of marriage with their spouse and, more importantly, with their in-laws. However, as with other legislative reforms in the realm of family law, this one may have turned out to benefit men much more than women, since women's rights to maintenance are mostly curtailed by their husbands' poverty. Furthermore, as the impressive NGO campaign against legal reform demonstrated, the nature of patriarchy that currently regulates marital conflicts hinges on the lack of direct state interference in imposing marital obligations. While this offers some space and freedom in which to negotiate marital conflicts, it appears to work best for women who have paternal relatives willing and able to take up their case vis-à-vis a husband in times of conflict. Phrased differently, the question remains how family law and related 
provisions can be reformed to protect and empower those who are in need of state protection, without producing consequences that work only to the advantage of men.

\section{BIBLIOGRAPHIE}

Newspaper and journal articles, court rulings and relevant legislation are quoted in full in the footnotes. All Arabic titles have been translated.

AL- ${ }^{\mathrm{C}}$ ALÎMî R., 1989, Traditionalism and Modernism in the Yemeni Legal System (in Arabic), Dâr alKalima, Sancâ'.

ARABI O., 2001, Studies in Modern Islamic Law and Jurisprudence, The Hague, London, NY, Kluwer Law International.

AL-BAKRî M., 3/1994, Encyclopedia of Personal Status Law and Jurisprudence (in Arabic), Dâr Mahmûd, Cairo.

Civic Democratic Initiatives Support Foundation/Women Affairs Support Center, 2002: Bayt al-tấ ${ }^{c} a$ : Another Success Story (in Arabic), San'â'.

DoRsKY S., 1981, Women's Lives in a North Yemeni Highlands Town, Ph.D. thesis, Case Western Reserve University.

DREsCH P., 1989, Tribes, Government, and History in Yemen, Oxford, Clarendon Press.

FlueHr-Lobban C. and Bardsley-Sirois L., 1990, “Obedience ( $\left.\mathrm{Ta}^{\prime} \mathrm{a}\right)$ in Muslim Marriage: Religious Interpretation and Applied Law in Egypt, Journal of Comparative Family Studies 21,1.

GloSEMEYeR I., 1999, “The Development of State Institutions”, in Remy Leveau, Franck Mermier, Udo Steinbach (eds), Le Yémen contemporain, Paris, Karthala.

Mundy M., 1995, Domestic Government: Kinship, Community and Polity in North Yemen, London, I. B. Tauris.

[RoY, Parliamentary Committee, no date $]=$ RoY Parliament, Committee for Justice and Endowments (no date): Report of the Committee on the draft amendment of republican decree 28/1992 on civil procedure and execution of judgements (in Arabic), San'â'.

Women's Affairs Support Center (no date), Program of Judicial and Legal Cadres Awareness Raising About Violence Against Women. Final Report, Sancâ'.

WÜRTH A., 2003, "The State, Activism and Social Class: Family Law Reform in Post-Unification Yemen", Islamic Law and Society 10 (1).

-, 2000, al-sharîca fî Bâb al-Yaman: Recht, Richter und Rechtspraxis an der familienrechtlichen Kammer des Gerichtes Süd-Sanaa (Republik Jemen) 1983-1995, Berlin, Duncker \& Humblot. 


\section{NOTES}

1. On Egyptian norms and jurisprudence, see al-Bakrî 1994, 696f., 700ff.; Fluehr-Lobban/BardsleySirois 1990, 41f., 46f.

2. My thanks to judges Amîn al-Mishwalî and Muhammad Humrân for kindly allowing me to study these rulings.

3. The small sample size leads me to use this material in a purely illustrative fashion; it is certainly not a representative or exhaustive treatment of jurisprudence in $t \hat{a}^{c} a$ cases.

4. During the 1970s, women in rural areas would also turn to local shaykhs or judges.

5. 31/1422, A.A.H. vs. Kh.A.D., 25. Shacbân 1422, 11.11.2001. All rulings quoted were issued by the Appeal Court for San'â' and al-Jawf; the arbitration decisions are likewise taken from these rulings where they are quoted verbatim.

6. For a contrasting, rather idealized account, see Dorsky 1981:161ff.

7. Arbitrators are appointed by the parties themselves, and are often tribal or military leaders, or, more generally, notables of a location, known for their knowledge of legal procedures and their capacity to force parties to comply with a ruling. Arbitration is regulated under Yemeni law; rulings by arbitrators are considered as primary court judgements and, after registration at the competent court, are subject to enforcement or appeal: Presidential Decree on Law of Arbitration 22/1992 as amended by Law 32/1994, Articles 54, 56, 58.

8. The term disobedience (nushûz) does not explicitly feature in Yemeni family law.

9. I have dealt with the doctrinal development of Yemeni Personal Status Law in detail elsewhere, Würth 2000:84-113, particularly 96-99.

10. Imâm Yahyâ Hamîd al-Dîn, however, had held in his "opinions" (ikhtiyârât) published in 1933 that a "disobedient" wife and/or her guardian could be temporarily jailed for "discipline", as could be a husband not willing to pay maintenance. Unlike many of Imâm Yahyâ's other opinions, neither of these was incorporated into later family or procedural law.

11. However, a court order on maintenance that has not been paid up often serves as proof of the husband's failure to provide, in wife-initiated divorce proceedings.

12. According to a 2001 survey in 65 courts, the San'â'-based Women's Affairs Support Center found that claims for maintenance were more frequent (41.4\%) than those for marital obedience (17.3\%). Women's Affairs Support Center, no date, 12/13, 23, 26. Unfortunately, the survey did not specify the maintenance cases in more detail, nor the type of courts they surveyed (primary/ appeal), nor the urban/rural divide in their survey. Data from my earlier research in a Sancâ' First Instance Court likewise indicate that maintenance claims by women were far more frequent during the 1980s and early 1990s than suits for restitution of marital rights. Since mostly women were using the court, this is not really surprising; tâca claims were, however, the most numerous cases raised by men in front of the court. For details, see Würth 2000:143, 146.

13. I have never seen a judge issuing such an order, but witnessed frequently that other law enforcement agencies did. Judges confirmed that this is current practice if the husband is insistent enough and willing to pay.

14. Adequate housing is an important issue among those recently married, and for women who have a co-wife/wives.

15. For data from a San'â' First Instance Court, see Würth 2000, 144, 162-188.

16. Even though the value of the Yemeni Riyal fluctuated considerably during the past years, I have calculated on a mean yearly basis of YR150 to the US\$.

17. 23/1419, M.H.Q. vs. H.Gh.H., 8. Rabîca I 1420, 21.6.1999.

18. 36/1420, Y.A.K. vs. A.A.K., 16. Rajab 1420, 25.10.1999.

19. Without a no./without a year, S.M.'A. vs. 'I.A.S., 18. Shawâl 1420, 24.1.2000.

20. 59/1422, M.M.J. vs. H.Q.H., 13. Dhû al-Qa'da 1422, 26.1.2002.

21. Without a no./without a year, S.M.'A. vs. 'I.A.S., 18. Shawâl 1420, 24.1.2000. 
22. Law of Arbitration, Article 5 (a) prevents arbitrators to validate a wife-initiated divorce.

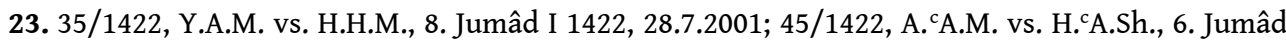
II 1422, 25.8.2001.

24. Without a no./1422, M.M.Z. vs. Kh.A.'A., no date.

25. Without a no./without a year, S.M.'A. vs. 'I.A.S., 18. Shawâl 1420, 24.1.2000.

26. 45/1422, A.'A.M. vs. H.c A.Sh., 6. Jumâd II 1422, 25.8.2001; 35/1422, Y.A.M. vs. H.H.M., 8. Jumâd I $1422,28.7 .2001$.

27. 5/1422, L. ${ }^{c}$ A $A$. vs. F.M.Q., 22. Muharram 1422, 16.4.2001. The failure to establish the wife's consent for $\mathrm{khul}^{\mathrm{c}}$ concluded under customary law is also the subject of many cases brought to primary courts by women, particularly if the khulc involved giving up custody; see below and Würth 2000:227-231 for examples.

28. 36/1420, Y.A.K. vs. A.A.K., 16. Rajab 1420, 25.10.1999.

29. Without a no./without a year, S.M.'A. vs. 'I.A.S., 18. Shawâl 1420, 24.1.2000.

30. 36/1420, Y.A.K. vs. A.A.K., 16. Rajab 1420, 25.10.1999.

31. 2/1421 M.A.J. vs. D.A.H., 22. Rabî‘a I 1421, 24.6.2000.

32. It should be added that many women, particularly in urban areas, may have no access or very limited access to arbitration to begin with. Those include women without male relatives, women of foreign or binational descent and very poor women.

33. 1/1422, M.A.M. vs. A.M.Sh., 8. Rabî`a I 1422, 30.5.2001. Probably considering that these events had occurred more than one-and-a half-years ago and the wife had remarried in the mean time, the Court of Appeal did not void the divorce. They first questioned the wife on whether she would return to her former husband, which she denied fervently, saying that she hated him. Then, in a session declared to be the final attempt at a settlement between the couple, the wife's family paid the husband another YR100.000 (US\$667), which he accepted. The court thus turned a repudiation under force for YR10.000 into a consensual khulc for ten times the amount and validated the divorce.

34. 23/1419, M.H.Q. vs. H.Gh.H., 8.Rabî̀a I 1420, 21.6.1999.

35. 36/1420, Y.A.K. vs. A.A.K., 16. Rajab 1420, 25.10.1999.

36. 59/1422, M.M.J. vs. H.Q.H., 13. Dhû al-Qacda 1422, 26.1.2002.

37. Abdallah Sinân al-Jalâl (born 1945) ran successfully for Islâh in the 1997 elections in Tacizz; he has a law degree and used to work as a teacher.

38. These were Muhammad Ahmad Margham, Professor for Civil Procedure and President of Judicial Inspection at the niyâba, Dr. Ibrahim Muhammad al-Sharafî, Professor for Civil Procedure, and Sacîd Khâlid al-Sharcabî, Professor for Civil Procedure: RoY, Parliamentary Committee, no date, 5-6.

39. The respective articles were taken verbatim from the Egyptian Code of Criminal Procedure 13/1968, Art. 494 (1).

40. RoY, Parliamentary Committee, no date, 242.

41. Islâh-MP since 1993, rapporteur in the constitutional parliamentary committee. 'Alaw also runs a private law firm, and two human rights NGOs, "al-Nushatâ" and the "National Organisation for Defending Rights and Freedoms" (the groups' own translation of al-ha'iya alwataniyya lil-difâa an al-huqûq wal-hurrîyât al-âmma).

42. As related in Civic Democratic Initiatives Support Foundation/Women Affairs' Support Center 2002, 3 .

43. As quoted in "Draft Law allowing the return to bayt al-tấca!", Al-Qistâs 41, January 2002, 8-9.

44. Al-Nâs 2 December 2001, al-Wahdawî 11 December 2001, al-Ayyâm 8 January 2002.

45. For the concluding observations of the CEDAW committee on Yemen's 1993 and 2002 periodic reports, see http://www.bayefsky.com/./html/yemen_t4_cedaw.php [24.3.2003].

46. Civic Democratic Initiatives Support Foundation/Women's Affairs' Support Center 2002:6.

47. For extensive coverage, see al-Ayyâm 10 January 2002, al-Thawrî 10 and 17 January 2002. 
48. Al-Thaqâfiyya 10 January 2002.

49. Al-Usra 2 February 2002.

50. Al-Usra 16 February 2002.

51. Yemen Times 28 January 2002.

52. Al-Thawrî 17 January 2002. Jâr Allah ${ }^{\mathrm{C}}$ Umar and other YSP officials, however, also pointed to a purportedly larger political dimension: "Why does this happen now? Why was it impossible that this would have happened seven years ago [that is, before the 1994 war between armies of the former ARY and PDRY]? ... A social transformation (inqilâb) has occurred, and we have to expect the worst ... We can sit down with the jurists (fuqahâ') and discuss the matter legally ... but in my view this is not a legal (fighî) but a political ... and programmatic issue ... an issue of hegemonic political forces. These forces attempt to impose their program on Yemeni society. They want us to be an underdeveloped society ... [and] guarantee the interests of certain social and political classes and groups (f'ât) and forces - this is how the matter should be discussed.", ibid.

53. Al-Thawrî 17 January 2002; al-Usra 19 January 2002.

54. Al-c Alîmî (1989) discusses in detail the tensions between what he calls foreign-educated modernists and traditionalists.

55. Muhammad Nâjî ${ }^{\mathrm{c}} \mathrm{Alaw}$, as quoted in al-Nâs 28 January 2002, and Muhammad al-Mikhlâfî (YSP) quoted in al-Thawrî 17 January 2002.

56. Al-Thawrî 17 January 2002.

57. Civic Democratic Initiatives Support Foundation/Women's Affairs' Support Center 2002:6, in their letter to the president; for a similar argument, see the discussions on the occasion of the Day of the Arab Family, reported in al-Mîthâq 14 January 2002.

58. Amal Bâshâ, as quoted in al-Usra 19 January 2002 and in a joint press statement by the Arabic Sisters' Forum and HRITC, 14 January 2002; Muhammad al- Mikhlâfî in al-Thawrî 17 January 2002.

59. Interview with activist Wahabiya Sabra, Sancâ', 2 March 2002. Hâshid and Bakîl are the major tribal confederations in the North and East of Yemen, and often at odds for political and other reasons.

60. Dhikrâ cAbbâs, "Marriage by force and marital life with threat (bil-samîl)," Al-Thawrî 17.1.2002.

61. 'Azza Bâsahîm, "No to bayt at-tấca, yes to consensual marital life (al-cishra alhusna)," al-Thawra 19.1.2002.

62. Faysal al-Sûfî, "Obedience ... by force," al-Qistâs 41, January 2002:10.

63. Ahmad al- Wâda'î, "Bayt at- tâc $a$ and the Justice Committee," al-Ayyâm 29 January 2002.

64. Muhammad Ismâcîl al-c'Amrânî, as quoted in al-Nâs 14 January 2001; Muhammad Ahmad alShâmî is reported as having said that "it is not permitted to force a woman in any of the matters concerning her": al-Ayyâm 19 January 2002. The Yemeni faskh al-karâhiya is basically a judicially supervised khul, roughly comparable to what was recently enacted in Egypt (see Arabi 2001:169-188). Under Yemeni law, the wife has to state her reasons for "hating" her husband, and, if these seem acceptable to the judge, she pronounces the dissolution of marriage and is obliged to return her mahr.

65. Al-Ayyâm 23 January 2002; al-Mîthâq 4 February 2002; excerpts in al-Sahwa 17 January 2002.

66. This wording allows me to assume that the committee's reply to the press might have been authored by somebody in the committee who was not entirely familiar with Yemeni personal status law, since the latter does not have provisions on talâq/tatlîq lil-darar or khulc lil-karâhiya.

67. According to the constitution of 1994 as last amended in 2001, the president has a right to interfere in legislation by returning a passed law to parliament. Because of the lack of trust in the elected parliament, activists have often requested the president to use this right, thus making him the final arbiter on touchy issues. The president has used his right previously in respect of amendments to the personal status in 1997, see Würth 2000:84.

68. Al-Nâs 2 December 2001; al-Wahdawî 11 December 2001; "Draft Law allowing the return to bayt al-tấca!", al-Qistâs 41, January 2002:8-9. 
69. Interview with Amal Bâshâ, Head of the Arabic Sisters' Forum, Sancâ', 7 March 2002.

70. Al-Nahâr 15 January 2002.

71. See Butûl's article "Islam and dangerous interpretations": al-Thaqâfiyya 10 January 2002.

72. Al-Wahda, no date.

INDEX

Mots-clés : coutume, droit, islam

\section{AUTEUR}

\section{ANNA WÜRTH}

Université de Richmond (Virginie) 